\title{
SIMULASI PEMBELAJARAN CONCURRENCY PADA MATA KULIAH SISTEM OPERASI BERBASIS MULTIMEDIA
}

\author{
${ }^{1}$ Erwin Yulianto ${ }^{2}$ Galih Abdul Fatah Maulani \\ ${ }^{1}$ Universitas Langlangbuana, Indonesia \\ ${ }^{2}$ Universitas Garut, Indonesia \\ ${ }^{1}$ rwinyulianto@yahoo.com \\ ²galihafm@uniga.ac.id
}

\begin{abstract}
The course of the operating system is one of the compulsory subjects that must be taught to students who take the majors / study program of informatics engineering / information systems and information technology. This course introduces students to the concept of the operating system, the types of operating systems that used in everyday life, the general services owned by the operating system, and to learn the techniques and algorithms used in the services management implementation of in the operating system. The operating system is a program that acts as an intermediary between the user, the application program and the hardware. Some common services owned by the operating system include process scheduling management, resource management, memory management, file systems, network management, security management, storage management, and input-output device management. In this research, the discussion will be pursed into one of the Operating System service that is process scheduling management. One of the derivative material of process scheduling that is difficult for students to understand is Concurrency. In general, concurrency is the processes (more than one process) that occur at the same time. Some of the algorithms used in the application of concurrency in process management include Dining Philosophers, Banker Algorithm, Producer-Consumer, and Readers-Writers. Explanations related to these four algorithms require logic and a high degree of seriousness. Unfortunately not all students are able to maintain their concentration in a long time to learn the logic flow of the four algorithms. Based on the above description, the authors want to design a software that is able to simulate the four algorithms into the form of multimediabased learning media that is expected to increase the attractiveness and capture power of students who study it.
\end{abstract}

Keywords : Simulation, Concurrency, Operating System, Multimedia

\begin{abstract}
Abstrak : Mata kuliah sistem operasi merupakan salah satu mata kuliah wajib yang harus diajarkan kepada mahasiswa yang mengambil jurusan / program studi teknik informatika / sistem informasi / teknologi informasi. Mata kuliah ini memperkenalkan kepada mahasiswa mengenai konsep sistem operasi, jenis-jenis sistem operasi yang digunakan dalam kehidupan sehari-hari, layanan-layanan umum yang dimiliki oleh sistem operasi, dan mempelajari teknik dan algoritma yang digunakan dalam penerapan / pengelolaan layanan di sistem operasi. Sistem operasi adalah suatu program yang bertindak sebagai perantara antara user, program aplikasi dan perangkat keras. Beberapa layanan umum yang dimiliki oleh sistem operasi antara lain manajemen penjadwalan proses, manajemen sumber daya (resource), manajemen memori, sistem berkas, manajenen jaringan, manajemen keamanan, manajemen penyimpanan, dan manajemen perangkat masukan-keluaran. Dalam penelitian kali ini, pembahasan akan dikerucutkan ke dalam salah satu layanan Sistem Operasi yaitu manajemen penjadwalan proses. Salah satu materi turunan dari manajemen proses yang sulit untuk dipahami oleh mahasiswa adalah Concurrency. Secara umum concurrency merupakan proses-proses (lebih dari satu proses) yang terjadi pada saat bersamaan. Beberapa algoritma yang digunakan dalam penerapan concurrency pada manajemen proses antara lain Dining Philosophers, Banker Algorithm, Producer-Consumer, dan Readers-Writers. Penjelasan terkait keempat algoritma tersebut membutuhkan logika dan tingkat keseriusan yang tinggi. Sayangnya tidak semua mahasiswa mampu untuk mempertahankan konsentrasinya dalam waktu yang lama untuk mempelajari alur logika dari keempat algoritma tersebut. Berdasarkan uraian di atas, penulis ingin merancang suatu perangkat lunak yang mampu untuk mensimulasikan keempat algoritma tersebut ke dalam bentuk media pembelajaran berbasis multimedia sehingga diharapkan akan meningkatkan daya tarik dan daya tangkap dari mahasiswa yang mempelajarinya.
\end{abstract}

Kata Kunci : Simulasi, Concurrency, Sistem Operasi, Multimedia

\section{PENDAHULUAN}

Sistem operasi adalah suatu program yang bertindak sebagai perantara antara user, program aplikasi dan perangkat keras. Mata kuliah sistem operasi merupakan salah satu mata kuliah wajib yang harus diajarkan kepada mahasiswa yang mengambil jurusan / program studi teknik informatika / sistem informasi / teknologi informasi. Mata kuliah ini memperkenalkan kepada mahasiswa mengenai konsep sistem operasi, jenis-jenis sistem operasi yang digunakan dalam kehidupan sehari-hari, layanan-layanan umum yang dimiliki oleh sistem operasi, dan mempelajari teknik dan algoritma yang digunakan dalam penerapan / pengelolaan layanan di sistem operasi.

Salah satu layanan yang dimiliki oleh sistem operasi yaitu manajemen penjadwalan proses dan manajemen sumber daya (resource). Dalam penelitian kali ini, 
pembahasan akan fokus kepada materi concurrency, salah satu layanan Sistem Operasi yang merupakan materi turunan dari manajemen proses yang sulit untuk dipahami oleh mahasiswa. Secara umum concurrency merupakan proses-proses (lebih dari satu proses) yang terjadi pada saat bersamaan. Beberapa algoritma yang digunakan dalam penerapan concurrency pada manajemen proses antara lain Dining Philosophers (mewakili mutual exclusion), Banker Algorithm (mewakili deadlock), Producer-Consumer (mewakili bounded buffer), dan Readers-Writers (mewakili sinkronisasi / starvation).

Penjelasan terkait keempat algoritma tersebut membutuhkan logika dan tingkat keseriusan yang tinggi. Sayangnya tidak semua mahasiswa mampu untuk mempertahankan konsentrasinya dalam waktu yang lama untuk mempelajari alur logika dari keempat algoritma tersebut.

Berdasarkan uraian di atas, penulis ingin merancang suatu perangkat lunak yang mampu untuk mensimulasikan keempat algoritma tersebut ke dalam bentuk media pembelajaran berbasis multimedia sehingga diharapkan akan meningkatkan daya tarik dan daya tangkap dari mahasiswa yang mempelajarinya.

\section{KAJIAN PUSTAKA}

\section{II.1 Simulasi}

Pembuatan simulasi tidak lepas dengan bantuan program komputer untuk mewujudkannya. Simulasi komputer adalah program komputer yang berfungsi untuk menirukan perilaku sistem nyata tertentu, memiliki sifat Physical and Interactive. Simulasi adalah penggambaran suatu sistem atau proses dengan peragaan memakai model statistik atau pemeranan (Maulani, 2017). Simulasi merupakan pemodelan dari situasi real life ke dalam komputer sehingga dapat dipelajari bagaimana cara kerjanya (Yulianto \& Haryana, 2016). Definisi lain menurut Law dan Kelton (1991), simulasi merupakan sekumpulan metode dan aplikasi untuk menirukan atau mereprestasikan perilaku dari suatu sistem nyata, yang biasanya dilakukan pada komputer dengan menggunakan perangkat lunak tertentu.

Contoh dari simulasi komputer antara lain training simulation, medical simulator, city simulator (sim city), flight simulator, simulation game, engineering simulation, simulasi antrian layanan bank, simulasi perang, power plan simulation, dan lain-lain. Tahapan dalam mengembangkan simulasi komputer adalah (Febrian, 2002) :

1. Memahami sistem yang akan disimulasikan.

2. Mengembangkan model matematika dari sistem.

3. Mengembangkan model matematika untuk simulasi.

4. Membuat program (software) komputer.
5. Menguji, memverifikasi dan memvalidasi keluaran simulasi.

\section{II.2 Concurrency}

Konkurensi merupakan salah satu kejadian (event) di dalam manajemen proses, dimana proses-proses (lebih dari satu proses) yang terjadi pada saat bersamaan. Pada proses-proses konkuren yang berinteraksi mempunyai beberapa masalah yang harus diselesaikan, antara lain (Tandri, 2006) :

1. Mutual Exclusion, adalah jaminan hanya satu proses yang mengakses sumber daya pada satu interval waktu tertentu. Mutual Exclusion merupakan kondisi dimana terdapat sumber daya yang tidak dapat dipakai bersama pada waktu yang bersamaan (misalnya : printer, disk drive). Kondisi demikian disebut sumber daya kritis, dan bagian program yang menggunakan sumber daya kritis disebut critical region / section.

2. Sinkronisasi, adalah proses pengaturan jalannya beberapa proses pada saat yang bersamaan. Tujuan utama sinkronisasi adalah menghindari terjadinya inkonsitensi data karena pengaksesan oleh beberapa proses yang berbeda (mutual exclusion) serta untuk mengatur urutan jalannya proses-proses sehingga dapat berjalan dengan lancar dan terhindar dari race condition, deadlock dan starvation

3. Deadlock, suatu event dimana proses menunggu satu kejadian tertentu yang tak akan pernah terjadi. Sekumpulan proses berkondisi deadlock bila setiap proses yang ada di kumpulan itu menunggu suatu kejadian yang hanya dapat dilakukan proses lain yang juga berada di kumpulan itu. Proses menunggu kejadian yang tidak akan pernah terjadi.

4. Starvation, suatu event dimana proses kekurangan resource (karena terjadi deadlock) dan tidak pernah mendapat resource yang dibutuhkan sehingga mengalami starvation (kelaparan). Starvation juga bisa terjadi tanpa deadlock ketika terdapat kesalahan dalam sistem sehingga terjadi ketimpangan dalam pembagian resouce. Satu proses selalu mendapat resource, sedangkan proses yang lain tidak pernah mendapatkannya.

\section{II.3 Sistem Operasi}

Secara umum, sebuah sistem komputer terbagi atas hardware, sistem operasi, program aplikasi, dan user. Komponen-komponen sistem komputer tersebut ditunjukkan oleh gambar 1 berikut ini (Canharta, 2006). 


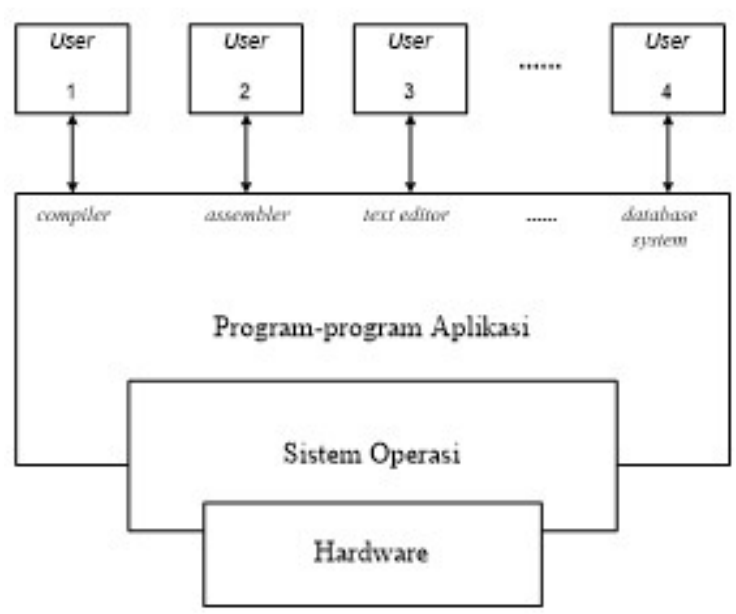

Gambar 1. Komponen-Komponen Sistem Komputer

Menurut Silberschatz, Galvin, dan Gagne (2007), pada umumnya sebuah sistem operasi modern mempunyai layanan-layanan sebagai berikut:

1. Manajemen Proses, proses adalah program yang sedang di eksekusi. Suatu proses membutuhkan satu atau beberapa sumber daya untuk menyelesaikan tugasnya. Sumber daya tersebut dapat berupa CPU time, memori, berkas-berkas, atau perangkat-perangkat I/O.

2. Manajemen Memori, memori adalah suatu array besar yang terdiri dari word atau byte, yang ukurannya dapat mencapai ratusan, ribuan, atau bahkan jutaan. Setiap word atau byte mempunyai alamat tersendiri. Memori berfungsi sebagai tempat penyimpanan data yang digunakan oleh $\mathrm{CPU}$ atau perangkat I/O. Memori merupakan tempat penyimpanan data yang sementara (volatile), artinya data dapat hilang begitu sistem dimatikan.

3. Manajemen Secondary Storage, data yang disimpan dalam memori bersifat sementara dan ukurannya sangat kecil jika dibandingkan dengan keseluruhan data yang terdapat dalam komputer. Oleh karena itu, untuk meyimpan keseluruhan data dan program komputer dibutuhkan secondary storage yang bersifat non volatile dan mampu menampung banyak data. Contoh dari secondary storage adalah harddisk, disket, dan lain-lain.

4. Manajemen Sistem I/O, fungsi ini sering disebut device manager dimana sistem operasi menyediakan device driver yang umum sehingga operasi I/O dapat seragam membaca atau menuliskan data tanpa mempedulikan mekanisme kerja yang berbeda dari perangkat-perangkat I/O yang ada.
5. Manajemen Arsip, file adalah kumpulan informasi yang dibuat dengan tujuan tertentu. File disimpan dalam struktur yang bersifat hirarkis, seperti direktori.

6. Sistem Proteksi, proteksi mengacu pada mekanisme untuk mengontrol akses yang dilakukan oleh program, prosesor, atau pengguna ke sistem sumber daya.

7. Sistem Jaringan, mendukung penggunaan jaringan. Sistem ini umumnya kini telah terpadu dalam sistem operasi karena kebutuhan kinerjanya serta kebutuhan komputasi telah menghendaki kemampuan ini

8. User Interface (Shell), Sistem Operasi menunggu instruksi dari pengguna (command driven). Program yang membaca instruksi dan mengartikan control statements disebut controlcard interpreter atau command-line interpreter. User Interface sangat bervariasi dari satu sistem operasi ke sistem operasi yang lain dan disesuaikan dengan tujuan dan teknologi $I / O$ devices yang ada. Contohnya: Command Line Interface (CLI), Graphical User Interface (GUI), dan lain-lain.

\section{II.4 Multimedia}

Multimedia yang berasal dari kata multi yang berarti banyak atau lebih dari satu dan media yang dapat diartikan penyajian suatu tempat. Multimedia adalah pemanfaatan komputer untuk membuat dan menggabungkan teks, audio, gambar, bergerak (video dan animasi dengan menggunakan link dan tool yang memungkinkan pemakai (user) melakukan navigasi, berinteraksi, berkreasi dan berkomunikasi (Suyanto, 2004).

Definisi lain dari multimedia menurut Hofstetter (2001) adalah penggunaan komputer untuk menampilkan informasi yang merupakan gabungan dari teks, grafik, audio dan video sehingga membuat pengguna dapat bernavigasi, berinteraksi, berkreasi dan berkomunikasi dengan komputer. Selain kombinasi dari objek-objek multimedia tersebut, terdapat juga 4 komponen penting lainnya, yaitu:

1. Adanya komputer untuk mengatur apa yang akan dilihat dan didengar, dan apa yang akan berinteraksi dengan penggunanya

2. Adanya link-link yang menghubungkan informasi-informasi yang tersedia

3. Adanya tool-tool navigasi bagi pengguna agar dapat menggunakan informasi yang tersedia

4. Adanya prosedur bagi pengguna untuk mengumpulkan, memproses dan menyampaikan informasi dan ide-idenya. 
Kelebihan multimedia adalah menarik indera dan minat, karena merupakan gabungan antara pandangan, suara dan gerakan. Lembaga Riset dan Penerbitan Komputer yaitu Computer Technology Research (CTR), menyatakan bahwa orang hanya mampu mengingat $20 \%$ dari yang dilihat dan $30 \%$ dari yang didengar, tetapi orang dapat mengingat $50 \%$ dari yang dilihat dan didengar dan $30 \%$ dari yang dilihat, didengar dan dilakukan sekaligus. Multimedia menjadi tool yang ampuh untuk pengajaran dan pendidikan (Suyanto, 2004).

\section{II.5 Dining Philosophers Problem}

Dining Philosophers Problem merupakan salah satu masalah klasik dalam mutual exclusion. Dining Philosohers Problem dapat diilustrasikan sebagaimana gambar 2 berikut, terdapat lima orang filsuf yang sedang duduk mengelilingi sebuah meja. Terdapat lima mangkuk mie di depan masing-masing filsuf dan satu sumpit di antara masing-masing filsuf. Para filsuf menghabiskan waktu dengan berpikir (ketika kenyang) dan makan (ketika lapar). Ketika lapar, filsuf akan mengambil dua buah sumpit (di tangan kiri dan tangan kanan) lalu makan, namun adakalanya, hanya terdapat satu sumpit saja. Jika ada filsuf yang mengambil dua buah sumpit, maka dua filsuf di samping filsuf yang sedang makan harus menunggu sampai sumpit ditaruh kembali. Hal ini dapat diimplementasikan dengan wait dan signal (Canharta, 2006).

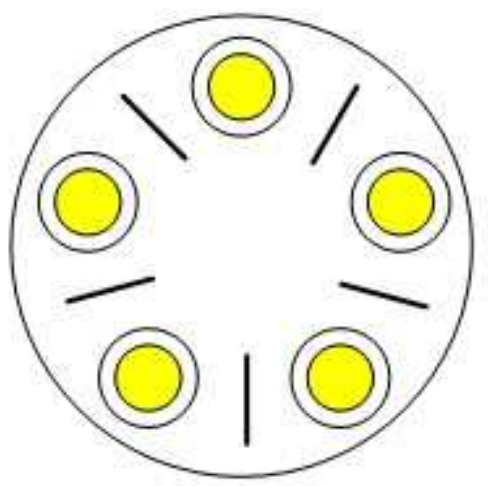

Gambar 2. Dining Philosohers Problem

Struktur proses atau dikenal dengan spesifikasi proses (PSPEC) dari Dining Philosohers Problem dapat dilihat pada algoritma di bawah ini :

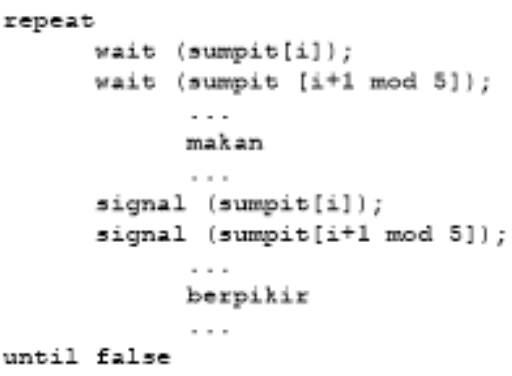

Meskipun solusi ini menjamin bahwa tidak ada 2 filsuf yang makan bersama-sama, namun masih mungkin terjadi deadlock, yaitu jika tiap-tiap filsuf lapar dan mengambil sumpit kiri, maka semua nilai sumpit $=0$, dan kemudian tiap-tiap filsuf akan mengambil sumpit kanan, maka akan terjadi deadlock.

\section{II.6 Banker Algorithm Problem}

Algoritma Banker dikemukakan oleh Edsger W.Dijkstra dan merupakan sebuah strategi untuk menghindari deadlock. Algoritma ini disebut algoritma Banker karena memodelkan banker di kota kecil yang berurusan dengan sekumpulan nasabah yang memohon kredit. Algoritma ini mencegah terjadinya deadlock dengan memutuskan apakah menyetujui atau menunda permintaan sumber daya oleh proses. Ketika sebuah proses meminta sumber daya, maka permintaan tersebut harus diperiksa oleh bankir. adalah :

Analogi dari algoritma Banker dengan sistem operasi

1. Nasabah, merupakan proses-proses yang sedang berjalan. Dalam algoritma Banker, setiap nasabah memiliki batas kredit dan apabila seorang nasabah telah mencapai batas kredit pinjaman maksimum, maka diasumsikan nasabah tersebut telah menyelesaikan semua permasalahan bisnisnya dan dapat mengembalikan semua pinjamannya kepada bank.

2. Bankir, merupakan sistem operasi. Bankir adalah seorang peminjam yang konservatif. Ketika sebuah proses (nasabah) meminta peminjaman sumber daya (uang), bankir melihat buku bank dengan cermat dan berusaha untuk memutuskan apakah peminjaman tersebut dapat menyebabkan keadaan deadlock (setelah peminjaman tersebut disetujui) atau tidak.

3. Uang, yaitu dana yang dimiliki bank merupakan sumber daya. Setelah peminjaman, akan terdapat sejumlah sumber daya tersisa di dalam sistem. Kita asumsikan masing-masing proses meminta batas maksimum sumber daya. Jika bankir memiliki cukup sumber daya yang tersisa untuk memastikan bahwa semua proses dapat berakhir 
dengan aman. Ini menunjukkan keadaan berada dalam safe state dan peminjaman disetujui.

Kelemahan dari algoritma Banker adalah setelah peminjaman, bankir tidak dapat menjamin semua proses dapat berakhir dengan semestinya, sehingga terjadi unsafe state. Dalam kasus ini, peminjaman akan ditunda atau diblok hingga peminjaman tidak menyebabkan unsafe state pada sistem. Pada algoritma Banker ini, kondisi mutual exclusion, hold-and-wait, dan no-preemption diijinkan dan proses-proses melakukan klaim penggunaan sumber daya yang diperlukan. Proses-proses diizinkan mengenggam sumber daya-sumber daya sambil meminta dan menunggu sumber daya lain, sementara sumber daya yang sedang digunakan itu tidak diijinkan untuk dipreempt oleh proses lain (Zhuang, 2006).

\section{II.7 Producer-Consumer Problem}

Kasus producer-consumer digunakan sebagai ilustrasi pembahasan sinkronisasi. Masalah producerconsumer disebut juga bounded-buffer problem (masalah buffer dengan jumlah terbatas). Asumsi yang digunakan dalam producer-consumer problem adalah sebagai berikut (Budiman, 2006):

1. Dua proses menggunakan suatu buffer yang dipakai bersama dan berukuran tetap.

2. Satu proses adalah producer yang meletakkan informasi ke buffer.

3. Proses lain adalah consumer yang mengambil informasi dari buffer.

Masalah producer-consumer dapat dikembangkan menjadi masalah yang memiliki $m$ buah produsen dan $n$ buah konsumen. Selanjutnya, dikarena buffer terbatas, masalah berikut dapat terjadi, yaitu:

1. Masalah untuk producer, terjadi ketika buffer telah penuh, sementara producer ingin meletakkan informasi ke buffer yang telah penuh itu.

2. Masalah untuk consumer, terjadi ketika consumer ingin mengambil informasi sementara buffer telah/sedang kosong.

Struktur proses pada producers-consumers problem dapat dilihat pada PSPEC di bawah ini.

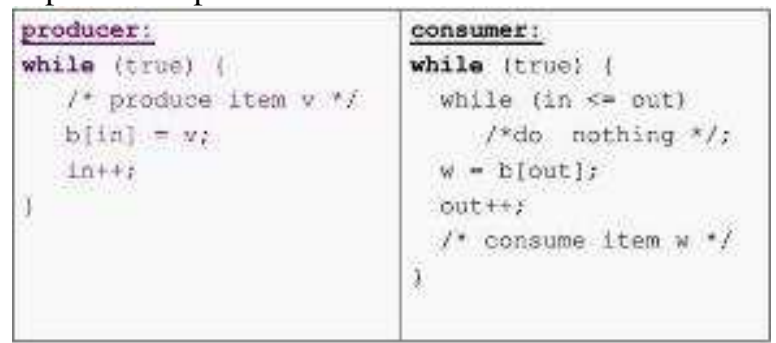

Kedua proses memerlukan sinkronisasi agar keduanya dapat menghindari masalah. Penyelesaian ini memiliki dua rutin, yaitu sleep dan Wake-up. Kedua rutin bersifat atomik, yaitu saat rutin dieksekusi maka tak ada interupsi yang dapat menyela (interupsi). Sleep adalah rutin yang menyebabkan pemanggil di-blocked, ditunda sampai proses lain membangunkan (Wake-up). Wake-up adalah rutin untuk membangunkan proses yang sedang berada dalam status sleeping. Wake-up mempunyai satu parameter, yaitu proses yang dibangunkan.

Solusi penyelesaian dengan sleep and wakeup adalah sebagai berikut (Budiman, 2006):

1. Solusi untuk masalah producer. Producer memanggil sleep setelah mengetahui buffer telah penuh saat producer akan menyimpan informasi ke buffer. Producer tidak lagi aktif kecuali dibangunkan (wake-up). Proses lain (consumer) akan memberitahu bahwa satu item atau lebih telah diambil dari buffer sehingga terdapat ruang bagi producer untuk menyimpan informasi kembali ke buffer.

2. Solusi untuk masalah consumer. Consumer memanggil sleep begitu mengetahui buffer telah kosong saat consumer mengambil item. Consumer tidak lagi aktif kecuali dibangunkan (wake-up) oleh proses lain (producer) yang memberitahu bahwa buffer telah terisi satu item atau lebih sehingga terdapat informasi yang dapat diambil consumer dari buffer.

\section{II.8 Readers and Writers Problem}

Masalah pembaca dan penulis (readers and writers problem) memodelkan pengaksesan lebih dari satu proses ke basis data yang sama. Masalahnya dapat dideskripsikan sebagai berikut, diasumsikan terdapat basis data besar seperti sistem reservasi penerbangan dengan proses-proses yang berkompetisi untuk membaca dan menulis pada basis data tersebut. Diasumsikan bahwa pada sistem basis data tersebut memiliki prosedur sebagai berikut (Tandri, 2006)

1. Sistem reservasi mengijinkan banyak proses membaca (reader) basis data pada saat yang sama.

2. Jika terdapat satu proses menulis / mengubah (writer) basis data, proses lain tidak boleh mengakses basis data baik membaca atau menulis.

Pada masalah ini, writers memiliki prioritas yang lebih tinggi daripada readers. Jika ada writer yang sedang menunggu, maka tidak boleh ada reader lain yang bekerja. Writer akan memblok semua proses reading dan melakukan proses writing. Ketika proses writing selesai, maka proses reading dapat dilanjutkan kembali oleh readers. Struktur proses pada readers and writers problem dapat dilihat pada PSPEC di bawah ini. 


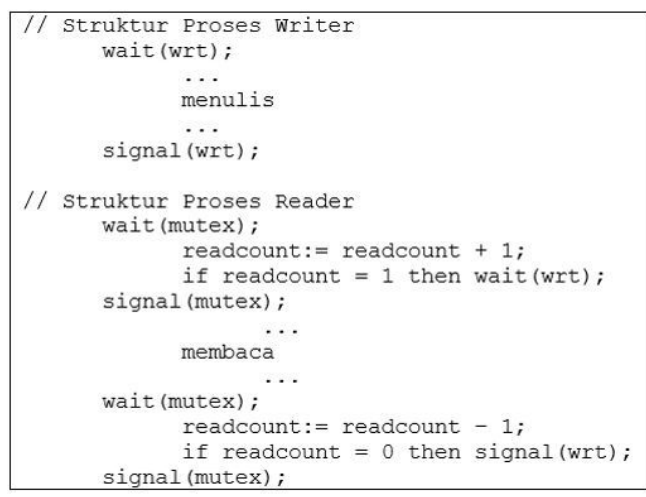

Algoritma di atas menunjukkan masalah reader dan writer. Jika ada writer dalam critical section dan ada $\mathrm{n}$ reader yang menunggu, maka satu reader akan antri di wrt, dan $\mathrm{n}-1$ reader akan antri. Jika writer mengeksekusi signal(wrt), maka dapat disimpulkan bahwa eksekusi adalah menunggu reader atau menunggu satu writer.

\section{METODE PENELITIAN}

Metode penelitian yang digunakan oleh penulis adalah metode deskriptif, yaitu penelitian yang dilakukan untuk mengetahui nilai variabel mandiri, baik satu variabel atau lebih (independen) tanpa membuat perbandingan, atau menghubungkan dengan variabel yang lain (Sugiyono, 2003). Teknik pengumpulan data yang digunakan teknik wawancara.

Adapun metode pengembangan sistem yang digunakan yaitu memakai tahapan siklus hidup perangkat lunak / software development life cycle (SDLC) dengan model prototyping. Adapun tahapan-tahapan aktivitas dari model prototyping dapat dilihat pada gambar 3 di bawah ini.

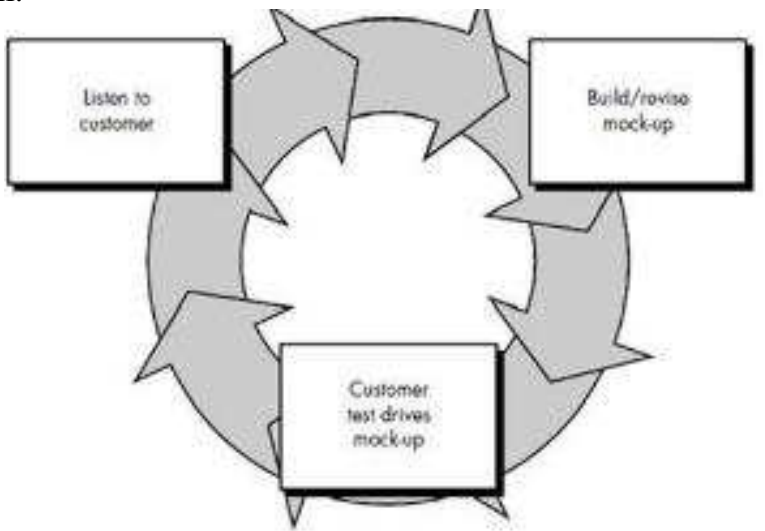

Gambar 2. Model Prototyping

Tahapan dari Model Prototyping merefleksikan pokok-pokok dari aktivitas pengembangan perangkat lunak sebagai berikut:

1. Listen to Customer
Pada tahap listen to customer, kegiatan penelitian dibagi menjadi 2 fase yaitu :

a. Persiapan Penelitian

Pada tahap ini penulis melakukan wawancara dengan mahasiswa dalam mengumpulkan data. Data yang menjadi fokus utama dalam penelitian ini yaitu bagaimana tingkat pemahaman mahasiswa terhadap salah satu silabus pada mata kuliah Sistem Operasi yaitu Konkurensi baik dari sisi konsep, alur proses, maupun algoritmanya.

b. Analisis

Pada tahap ini dilakukan identifikasi tingkat pemahaman mahasiswa terhadap mata kuliah Sistem Operasi berdasarkan hasil pengumpulan data nilai UTS. Data primer yang dibutuhkan adalah data nilai UTS selama 2 tahun terakhir.

2. Build/Revise Mock Up

Tahap ini merupakan desain sistem/perancangan model dan alur pembangunan simulasi pembelajaran konkurensi berbasis multimedia. Perancangan sistem yang dibuat meliputi pembuatan storyboard, tahapan proses, algoritma, simulasi tabel, dan sitemap design.

3. Customer Test Drives Mock-Up

Setelah tahap build/revise mock-up selesai, maka tahap terakhir yaitu customer test drives mock-up/pengujian prototype serta hasil analisis dari pengujian. Tahap ini merupakan tahap utama dari sistem yang dibuat karena pada tahapan ini dilakukan user acceptable test yang dilanjutkan dengan pengujian soal dan pengisian kuisioner untuk mengetahui pemahaman mahasiswa terkait sebelum dan setelah berinteraksi dengan simulasi pembelajaran konkurensi.

\section{PEMBAHASAN}

\section{IV.1 Spesifikasi Proses (PSPEK)}

Simulasi Pembelajaran Concurrency Pada Mata Kuliah Sistem Operasi Berbasis Multimedia memiliki 4 (empat) buah modul pembelajaran utama, yaitu Dining Philosophers Problem, Banker Algorithm Problem, Producer-Consumer Problem, dan Readers-Writers Problem.

Spesifikasi proses dari masing-masing modul dapat kita bahas sebagai berikut :

\section{Dining Philosophers Problem}

a. Jumlah filsuf : 5 (lima) orang

b. Jumlah sumpit : 5 (lima) buah

c. Kondisi status dari masing-masing filsuf :

i. Kenyang $\rightarrow$ Berpikir (detik) 


\section{ii. Lapar $\rightarrow$ Makan (detik) \\ iii. Kelaparan $\rightarrow$ Mati (detik)}

d. Storyboard:

Di dalam perangkat lunak, kondisi filsuf di atas dirancang penulis secara matematis menjadi waktu-A dan waktu-B.

i. Waktu-A, yaitu waktu yang diperlukan untuk mengubah kondisi filsuf dari kenyang menjadi lapar (dalam sekon).

ii. Waktu-B, yaitu waktu yang diperlukan untuk mengubah kondisi filsuf dari lapar menjadi mati (dalam sekon).

iii. Masa Hidup, yaitu masa hidup filsuf pada saat itu (dalam sekon). Maksimum masa hidup adalah sebesar nilai waktu-A + waktu-B. Masa hidup filsuf akan bertambah ketika filsuf sedang makan dan akan berkurang di luar status itu.

2. Banker Algorithm Problem

a. Objek yang terlibat :

i. Resource : jumlah uang yang dimiliki oleh bank

ii. Customer : batas maksimum pemberian kredit

iii. Bankir : pemutus kredit

iv. Kasir : perantara antara bankir dan customer

b. Storyboard:

i. Ketika customer memohon kredit, maka permohonan kredit tersebut harus diperiksa oleh bankir.

ii. Dalam algoritma Banker, setiap customer memiliki batas maksimum kredit dan apabila seorang customer telah mencapai batas maksimum kredit, maka diasumsikan customer tersebut tidak dapat mendapatkan pinjaman dan hanya dapat mengembalikan semua pinjamannya kepada bank secara bertahap. Ada kalanya, seorang customer dapat menyelesaikan semua permasalahan bisnisnya dan mengembalikan semua pinjamannya kepada bank sebelum mencapai batas kredit maksimum.

c. Algoritma Banker terdiri atas algoritma Safety dan algoritma Resource Request. Cara kerja dari masing-masing algoritma tersebut adalah sebagai berikut:

i. Algoritma Safety

a) Set nilai Work $=$ Available (Available = dana masih tersisa setelah peminjaman). b) Set nilai Finish[i] = False untuk semua customer.

c) Cari semua customer yang memiliki Needs (keperluan) lebih kecil atau sama dengan nilai Work. Besar Needs dihitung dengan mengurangkan nilai maksimum_resource_customer dengan nilai allocation_resource_customer).

d) Apabila tidak ada lagi customer dengan status Needs $<=$ Work, maka periksa apakah semua Finish[i] bernilai True. Apabila semua Finish[i] = True, maka kondisi setelah peminjaman adalah safe. Apabila tidak, maka kondisi setelah peminjaman adalah unsafe.

ii. Algoritma Resource Request

a) Jika permohonan kredit (Request) lebih besar dari sisa resource pada bank (Available), maka permohonan kredit ditunda (pending).

b) Bankir melakukan simulasi peminjaman resource kepada customer dimana available resource pada bank dikurangi dengan besar request.

c) Jalankan algoritma Safety.

d) Apabila algoritma Safety menghasilkan keadaan safe, maka permohonan kredit direalisasikan. Apabila algoritma Safety menghasilkan keadaan unsafe, maka permohonan kredit ditunda (pending).

3. Producer-Consumer Problem

a. Objek yang terlibat : producer, consumer, market (buffer)

b. Inisialisasi variabel :

i. Pengaturan pada Producer, yaitu jumlah producer, batas maksimum dan minimum bagi producer dalam satu kali produksi.

ii. Pengaturan pada Consumer, yaitu jumlah consumer, batas maksimum dan minimum bagi consumer dalam satu kali konsumsi.

iii. Pengaturan pada Market, yaitu batas ukuran maksimum dan minimum market.

c. Storyboard: 
i. Producer aktif memproduksi dan meletakkan item ke market (buffer). Aksi ini akan menambah jumlah item di dalam market.

ii. Consumer aktif mengambil item dari market (buffer) dan mengonsumsi item. Aksi ini akan mengurangi jumlah item di dalam market.

iii. Apabila market telah penuh atau jumlah item di dalam market telah mencapai batas maksimum, maka producer akan tidur (memanggil aksi sleep).

iv. Apabila consumer mengambil item dari market dan producer dalam keadaan sleep, maka consumer akan membangunkan (wake-up) producer.

v. Apabila market kosong atau jumlah item di dalam market telah mencapai batas minimum, maka consumer akan tidur (memanggil aksi sleep).

vi. Apabila producer meletakkan item ke market dan consumer dalam keadaan sleep, maka producer akan membangunkan (wake-up) consumer.

4. Readers-Writers Problem

a. Objek yang terlibat : readers, writers, database

b. Storyboard: writers memiliki prioritas lebih tinggi dari readers. Writers mempunyai hak menulis basis data kapan saja. Ketika writers ingin menulis dan readers sedang membaca basis data, maka readers akan diblok dan tidak boleh membaca basis data hingga writers selesai menulis.

c. Diagram proses dari Readers-Writers Problem dapat dilihat pada gambar 3 berikut.

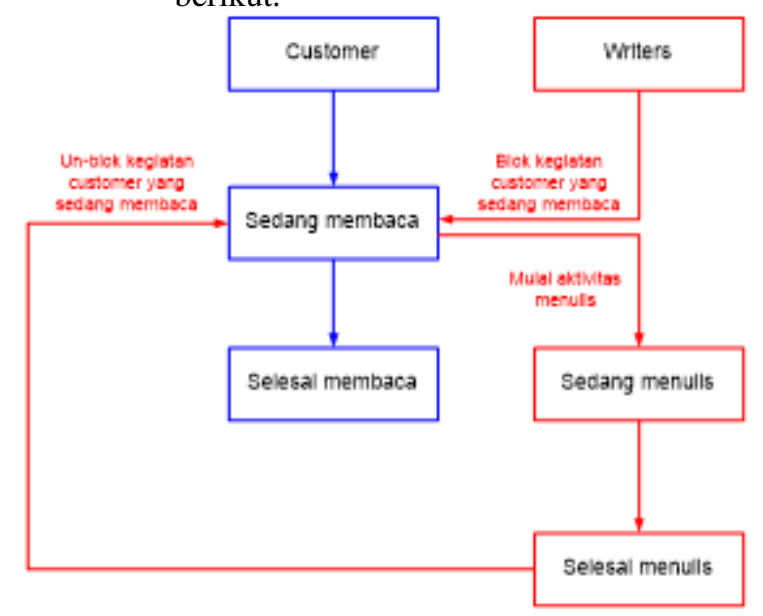

Gambar 3. Diagram Proses Readers-Writers Problem

\section{IV.2 Tabel Simulasi}

Pemodelan terhadap Simulasi Pembelajaran Concurrency Pada Mata Kuliah Sistem Operasi Berbasis Multimedia akan lebih mudah apabila digambarkan dalam bentuk tabel simulasi. Kita akan memakai studi kasus dari masing-masing modul untuk dibuat tabel simulasi yang akan dijelaskan sebagai berikut :

\section{Dining Philosophers Problem}

Langkah awal yang akan dilakukan adalah memberikan inisialisasi variabel awal sebagai berikut :
a. input PHILOSOPHERS $=5$
b. array of CHOPSTICKS $(1,2,3,4,5)$
c. array of PHILOSOPHERS_STATUS [Think, Eat, Hungry] = $(5,2,10) ;(4,4,10)$; $(3,6,10) ;(8,1,10) ;(6,3,10)$
d. array of PHILOSOPHERS_STICKS [Chopsticks1, Chopsticks2] = $(5,1) ;(1,2)$; $(2,3) ;(3,4) ;(4,5)$

maka tabel simulasi yang dapat dibuat dapat dilihat pada tabel 1 berikut

Tabel 1. Simulasi Dining Philosophers Problem

\begin{tabular}{|c|c|c|c|c|c|c|c|c|c|c|c|c|}
\hline & 1 & $z$ & 3 & 4 & 5 & 6 & $=$ & 8 & 10 & 70 & 48 & Iz \\
\hline$P_{1}$ & $\mathrm{~T}$ & I & $\mathrm{T}$ & $T$ & $\tau$ & $\mathbb{E}$ & I. & $\mathrm{I}$ & $T$ & $T$ & $\mathrm{~T}$ & T \\
\hline $\mathrm{P}_{2}$ & $T$ & $T$ & $T$ & $\mathrm{~T}$ & \#开 & H & H & $\mathrm{H}$ & $\mathrm{H}$ & B & E & E \\
\hline $\mathrm{P}_{3}$ & $T$ & $T$ & $T$ & F & ह & F & F. & E & F. & $r$ & $\mathrm{~T}$ & $T$ \\
\hline $\mathrm{P}_{4}$ & $r$ & II & I & $\tau$ & $\mathrm{T}$ & $\mathrm{T}$ & $\mathrm{T}$ & $\mathrm{T}$ & H & H & E & $\mathrm{T}$ \\
\hline$P_{5}$ & $T$ & I & $T$ & $\mathrm{~T}$ & $T$ & $t$ & H & E & E & B & $T$ & $T$ \\
\hline
\end{tabular}

2. Banker Algorithm Problem

Inisialisasi variabel awal banker algorithm problem dapat dideklarasikan sebagai berikut :
a. input NUMBER_OF_PROCESS = 5
b. input NUMBER_OF_RESOURCES $=3$
c. array of RESOURCES [index,instances] = $(1,10) ;(2,5) ;(3,7)$
d. array of PROCESS_RES_ALLOCATION $=[\mathrm{P}, \mathrm{R} 1, \mathrm{R} 2, \mathrm{R} 3]=(1,0,1,0) ;(2,2,0,0)$; $(3,3,0,2) ;(4,2,1,1) ;(5,0,0,2)$

e. array of PROCESS_RES_MAX $=[\mathrm{P}, \mathrm{R} 1$, R2, R3] = (1,7,5,3); $(2,3,2,2) ;(3,9,0,2)$; $(4,2,2,2) ;(5,4,3,3)$

maka tabel simulasi yang dapat dibuat dapat dilihat pada tabel 2 berikut

Tabel 2. Simulasi Banker Algorithm Problem

\begin{tabular}{|c|c|c|c|c|}
\hline Moerest & Mosulhas & Inte & Nemb & A Aw \\
\hline & ABC & AINE & $A B C$ & $A \| C$ \\
\hline po & ara & 75.3 & 248 & \multirow{5}{*}{5.82} \\
\hline Pr & 200 & 322 & $12 z$ & \\
\hline pas & 302 & 902 & 600 & \\
\hline$y_{3}$ & 211 & 202 & orz & \\
\hline$r_{4}$ & Daz & 433 & 435 & \\
\hline
\end{tabular}

\section{Producer-Consumer Problem}

Dengan memberikan inisialisasi variabel awal sebagai berikut :

e. int BUFFER_SIZE $=0$ 
f. int COUNTER $=0$

g. int ITEM $=0$

h. boolean PRODUCER $=$ False

i. boolean CONSUMER $=$ False

j. input BUFFER_SIZE $=10$

k. input COUNTER $=0$

1. array of PRODUCER $(2,0,5,8,4,0,6,0)$

m. array of CONSUMER $(0,3,0,0,0,6,0,3)$

maka tabel simulasi yang dapat dibuat dapat dilihat pada tabel 3 berikut

Tabel 3. Simulasi Producer-Consumer Problem

\begin{tabular}{|c|c|c|c|c|c|c|}
\hline$M / C$ & If cent & Chanter: & Relatians & 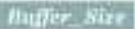 & M & ce \\
\hline - & $\alpha$ & 0 & $k$ & is & $\mathrm{T}$ & F \\
\hline M & 2 & 2 & $<$ & in & I & $\mathbf{T}$ \\
\hline c & 3 & 0 & $<$ & in & $\mathrm{r}$ & F: \\
\hline$M$ & 5 & 5 & $\infty$ & in & $\mathbf{T}$ & $\mathbf{T}$ \\
\hline $\mathrm{M}$ & 8 & I0 & so & in & F. & $\boldsymbol{T}$ \\
\hline$M$ & 4 & $\mathrm{R} \mathrm{n} d$ & Find & 10 & Knd & Frnd \\
\hline c & 6 & 4 & s & 10 & $T$ & $\mathbf{T}$ \\
\hline M & 6 & 10 & 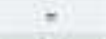 & 10 & F & $T$ \\
\hline c & 3 & 7 & $c=$ & 10 & $T$ & $\mathbf{T}$ \\
\hline
\end{tabular}

\section{Readers-Writers Problem}

Inisialisasi variabel awal dari readerswriters problem adalah sebagai berikut :
a. boolean ACTIVE=False
b. boolean WAIT $=$ False
c. array of READERS $[(2,2) ;(3,4) ;(5,3) ;(8,4) ;(9,4) ;(12,3) ;(16,3)]$
d. array of WRITERS $[(6,5) ;(10,6) ;(14,4)]$ maka tabel simulasi yang dapat dibuat dapat dilihat pada tabel 4 berikut

Tabel 4. Simulasi Readers-Writers Problem

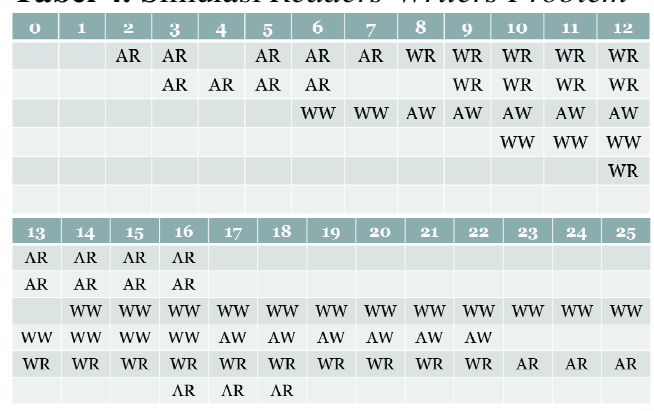

\section{IMPLEMENTASI}

Simulasi Pembelajaran Concurrency Pada Mata Kuliah Sistem Operasi Berbasis Multimedia yang dibangun berfungsi sebagai suplemen bahan ajar pada mata kuliah Sistem Operasi.

Tampilan antar muka dari fitur-fitur utama dari masing-masing modul dapat dilihat sebagai berikut :

1. Menu Utama simulasi Pembelajaran Concurrency, merupakan portal utama dari masing-masing modul dapat dilihat pada gambar 4 di bawah ini.

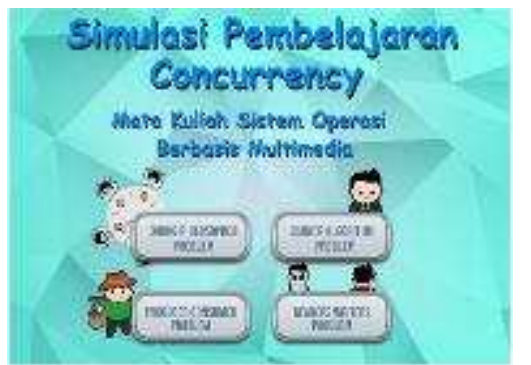

Gambar 4. Portal Utama (Dashboard)

2. Dining Philosophers Problem, fungsional yang akan ditampilkan antara lain :

a. Inisialisasi simulasi, dapat dilihat pada gambar 5 berikut.

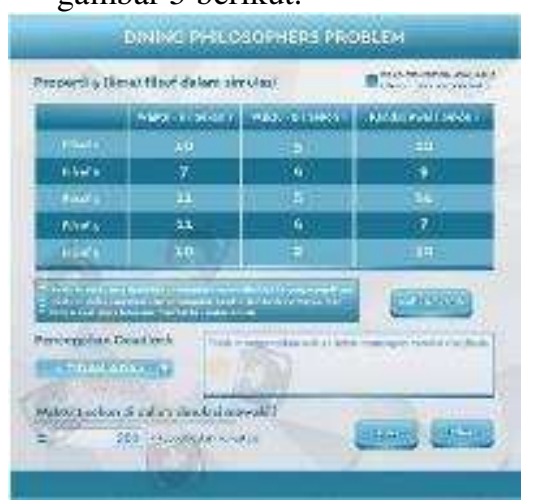

Gambar 5. Inisialisasi Simulasi Dining Philosophers Problem

b. Kondisi awal semua filsuf sedang berpikir dalam kondisi kenyang, dapat dilihat pada gambar 6 berikut.

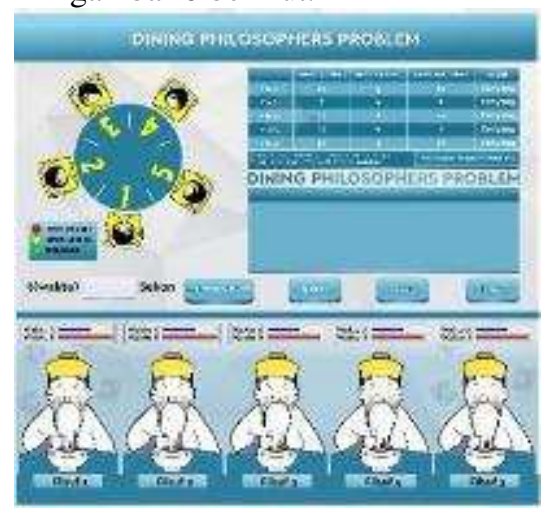

Gambar 6. Simulasi Kondisi Filsuf Berpikir Dalam Keadaan Kenyang

c. Kondisi dimana sebagian filsuf sedang makan dalam kondisi lapar dan sebagian filsuf sedang menunggu dalam kondisi lapar, dapat dilihat pada gambar 7 berikut. 


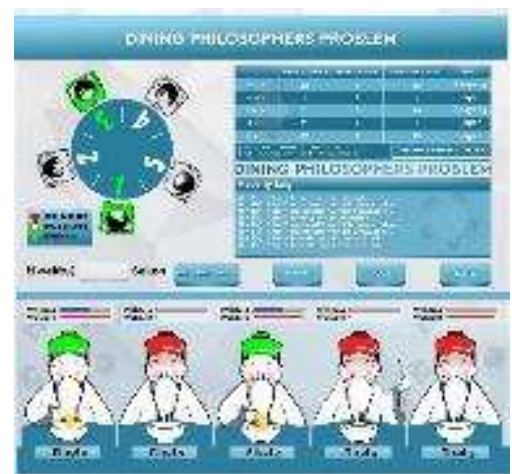

Gambar 7. Simulasi Kondisi Filsuf Sebagian Dalam Keadaan Lapar \& Sedang Makan

d. Kondisi dimana semua filsuf sedang menunggu dalam kondisi lapar sehingga terjadi status deadlock, dapat dilihat pada gambar 8 berikut.

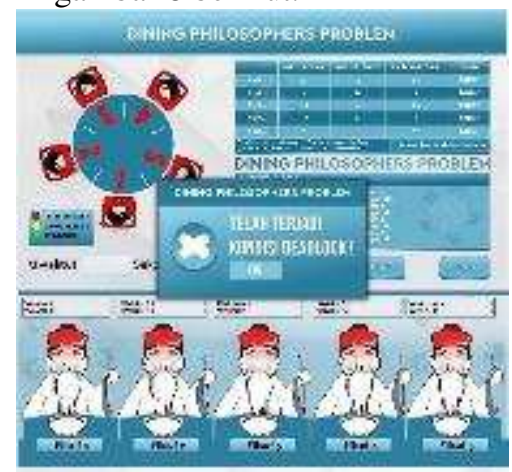

Gambar 8. Simulasi Kondisi Semua Filsuf Dalam Keadaan Lapar \& Menunggu (Deadlock)

3. Banker Algorithm Problem, fungsional yang akan ditampilkan antara lain :

a. Kertas kerja inisialisasi awal Banker Algorithm Problem, dapat dilihat pada gambar 9 berikut.

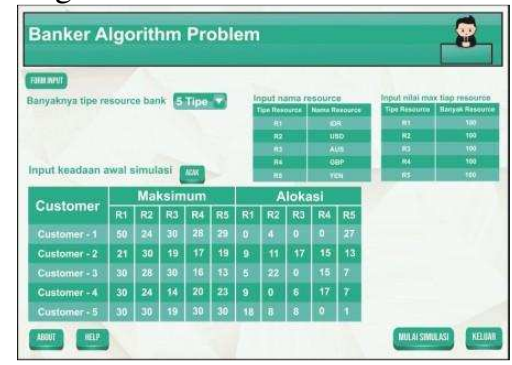

Gambar 9. Kertas Kerja Banker Algorithm Problem

b. Tampilan Awal Simulasi Banker Algorithm Problem, dapat dilihat pada gambar 10 berikut.

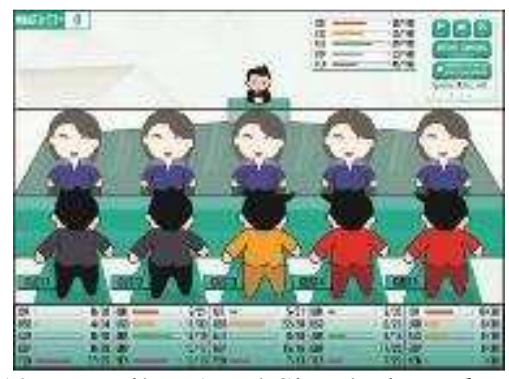

Gambar 10. Tampilan Awal Simulasi Banker Algorithm Problem

c. Simulasi Banker Algorithm Problem (Approved) dikarenakan kondisi safe state, dapat dilihat pada gambar 11 berikut.

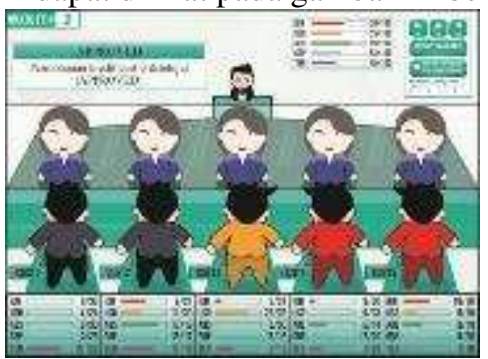

Gambar 11. Simulasi Banker Algorithm Problem (Approved)

d. Simulasi Banker Algorithm Problem (Pending) dikarenakan unsafe state, dapat dilihat pada gambar 12 berikut.

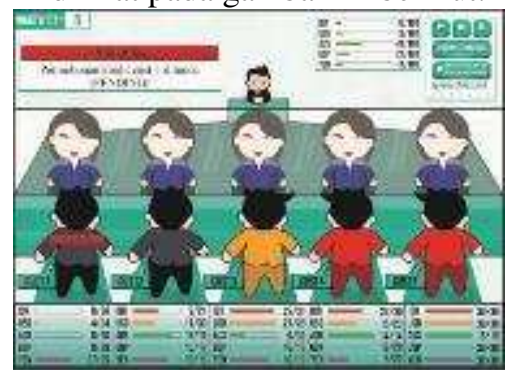

Gambar 12. Simulasi Banker Algorithm Problem (Pending)

e. History Proses Simulasi Banker Algorithm Problem, dapat dilihat pada gambar 13 berikut.

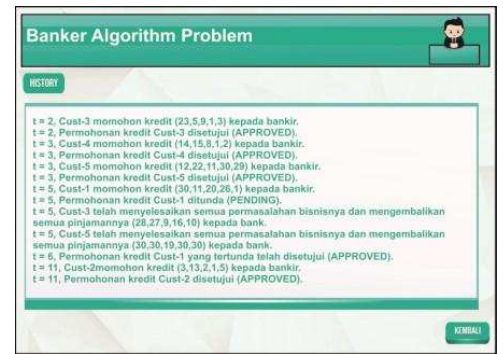


Gambar 13. History Proses Simulasi Banker Algorithm Problem

4. Producer-Consumer Problem, fungsional yang akan ditampilkan antara lain :

a. Kertas Kerja inisialisasi awal ProducerConsumer Problem, dapat dilihat pada gambar 14 berikut.

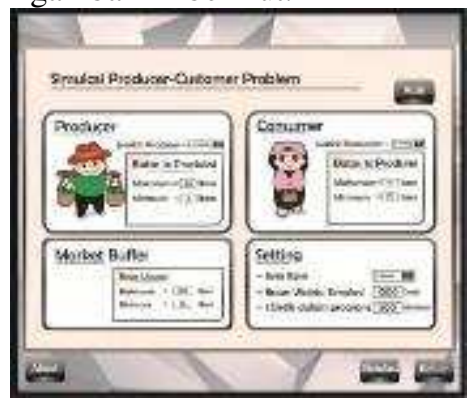

Gambar 14. Kertas Kerja Producer-Consumer Problem

b. Simulasi inisialisasi Producer-Consumer Problem, dapat dilihat pada gambar 15 berikut.

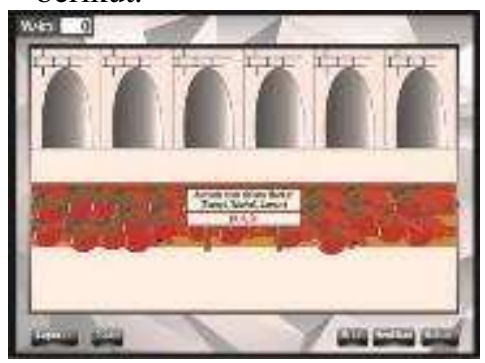

Gambar 15. Simulasi Producer-Consumer Problem (Inisialisasi)

c. Simulasi Producer - Consumer Problem dengan kondisi producer full, dapat dilihat pada gambar 16 berikut.

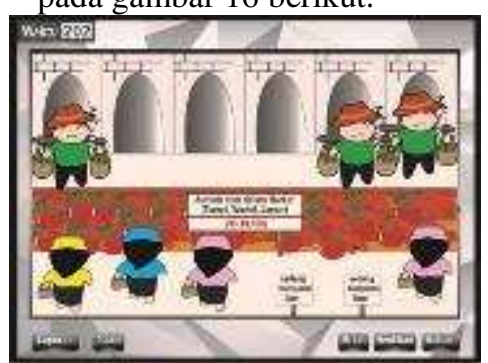

Gambar 16. Simulasi Producer-Consumer Problem (Producer Full)

d. Simulasi Producer - Consumer Problem dengan kondisi consumer full, dapat dilihat pada gambar 17 berikut.

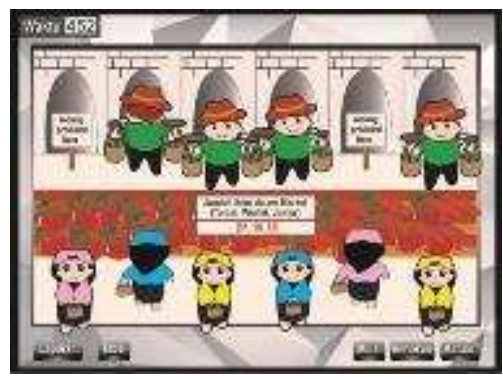

Gambar 17. Simulasi Producer-Consumer Problem (Consumer Full)

e. Proses Simulasi dalam bentuk Tabel pada Producer-Consumer Problem, dapat dilihat pada gambar 18 berikut.

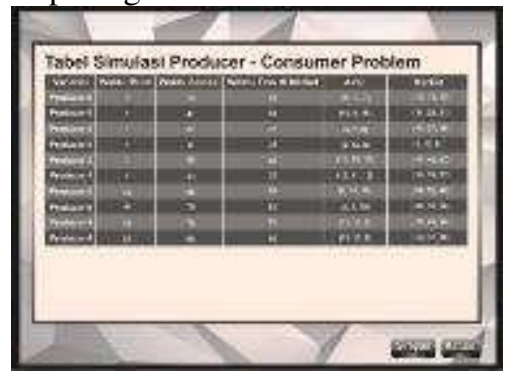

Gambar 18. Proses Simulasi (Tabel) ProducerConsumer Problem

f. History Proses Simulasi ProducerConsumer Problem, dapat dilihat pada gambar 19 berikut

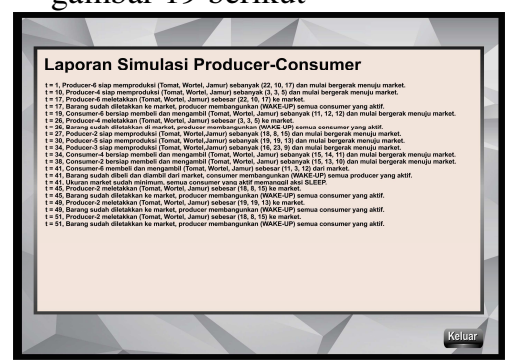

Gambar 19. History Proses Simulasi ProducerConsumer Problem

5. Readers-Writers Problem, fungsional yang akan ditampilkan antara lain :

a. Kertas Kerja inisialisasi awal ReadersWriters Problem, dapat dilihat pada gambar 20 berikut. 


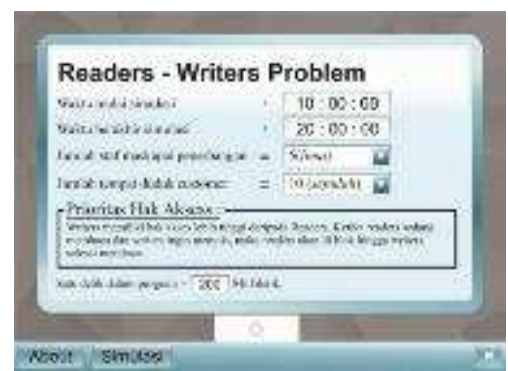

Gambar 20. Kertas Kerja Readers-Writers Problem

b. Proses simulasi Readers-Writers Problem dengan status running readers, dapat dilihat pada gambar 21 berikut.

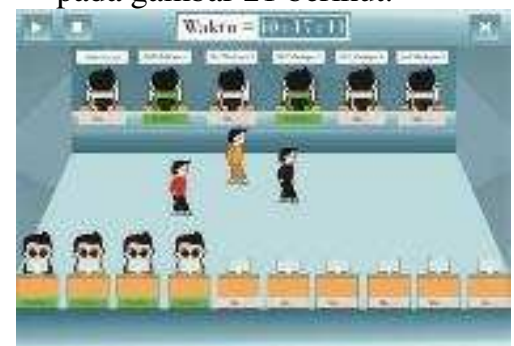

Gambar 21. Proses Simulasi (Reader Running)

c. Proses simulasi Readers-Writers Problem dengan status running writers, dapat dilihat pada gambar 22 berikut.

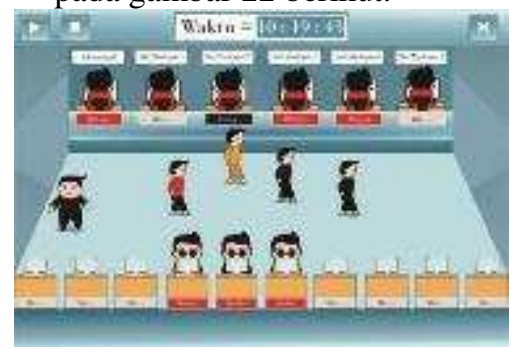

Gambar 22. Proses Simulasi (Writer Running)

d. Proses Simulasi dalam bentuk Tabel pada Readers-Writers Problem, dapat dilihat pada gambar 23 berikut.

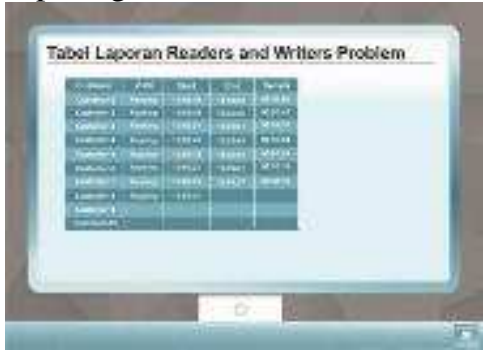

Gambar 23. Proses Simulasi (Tabel) Readers-Writers Problem e. History Proses Simulasi Readers-Writers Problem, dapat dilihat pada gambar 24 berikut.

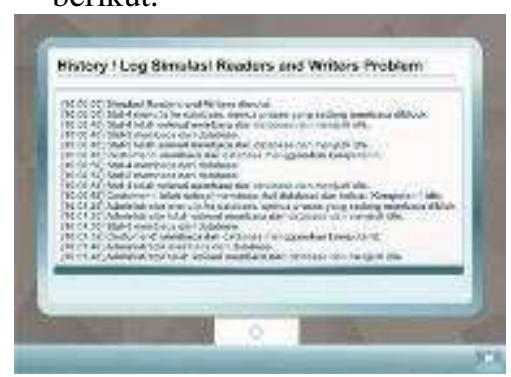

Gambar 24. History Proses Simulasi Readers-Writers Problem

\section{KESIMPULAN DAN SARAN}

\section{VI.1 Kesimpulan}

Berdasarkan analisis yang dilakukan pada penelitian terhadap penerapan Simulasi Pembelajaran Concurrency Pada Mata Kuliah Sistem Operasi Berbasis Multimedia yang dibangun dapat ditarik kesimpulan sebagai berikut:

1. Simulasi Dining Philosophers Problem, Banker Algorithm, Producer-Consumer Problem, dan Readers-Writers Problem mampu menjelaskan secara jelas salah satu materi Sistem Operasi yaitu konkurensi, dimana di dalamnya terdapat masalah-masalah seperti mutual exclusion, deadlock, sinkronisasi, dan starvation.

2. Solusi dari setiap permasalahan pada konkurensi sudah difasilitasi oleh simulasi seperti wait and signal, safe and unsafe state, resource request, sleep and wake up (semaphore), dan mutex signal

3. Simulasi Pembelajaran Concurrency Pada Mata Kuliah Sistem Operasi yang sudah dikembangkan sudah memenuhi persyaratan Multimedia yaitu pemanfaatan media elektronik seperti PC dan laptop untuk mem-visualisasikan alur proses dari keempat algoritma yang dipelajari ke dalam gambar bergerak, audio, musik, link, dan tombol sehingga memungkinkan user berinteraksi dengan sistem

\section{VI.2 Saran}

Beberapa saran dan masukan berikut diharapkan dapat memberikan perbaikan dalam penelitian selanjutnya, yaitu:

1. Simulasi Pembelajaran Pada Mata Kuliah Sistem Operasi perlu ditambahkan materinya agar lebih lengkap sesuai dengan silabus yang sudah disusun.

2. Peningkatan simulasi dari gambar bergerak menjadi animasi yang lebih halus dilengkapi 
dengan konsep / landasan teori berbasis audio visual.

3. Penambahan kertas kerja berbasis web untuk lebih meningkatkan daya tangkap mahasiswa memakai media tabel simulasi.

4. Penambahan database agar setiap aktivitas simulasi dapat tersimpan dengan baik dan dapat dipanggil sewaktu-waktu.

\section{Daftar Pustaka}

[1] Budiman, Willy. 2006. Perangkat Lunak Simulasi Producer-Consumer Problem. Medan: STMIK Mikrosil

[2] Canharta, Victor. 2006. Dining Philosophers Problem Simulation. Medan: STMIK Mikrosil

[3] Febrian, Jack. 2002. Kamus Komputer dan Istilah Teknologi Informasi. Bandung: Informatika

[4] Hofstetter. 2001. Multimedia Literacy. Boston: Irwin/McGraw-Hill

[5] Law, Averill M., Kelton, W. David. 1991. Simulation Modeling \& Analysis, Second Edition, McGraw-Hill

[6] Maulani, G. A. F. 2016. Rancang Bangun Aplikasi Ensiklopedia Digital Tentang Tata Surya Berbasis Mobile Menggunakan J2ME. JURNAL PETIK, 2(2), 11-16.

[7] Silberschatz, Avi., Galvin, Peter., Gagne., Greg. 2007. Operating System Concepts 8 Ed. John Wiley $\&$ Sons, Inc.

[8] Sugiyono. 2003. Metode Penelitian Bisnis. Bandung: Alfabeta

[9] Suyanto., M. 2004. Aplikasi Desain Grafis Untuk Periklanan. Yogyakarta: Andi

[10] Tandri, Tomi. 2006. Simulasi Readers And Writers Problem Pada Maskapai Penerbangan Di Bandara. Medan: STMIK Mikrosil

[11] Yulianto, Erwin., Haryana, KM Syarif. 2016. Simulasi Kinematika Interaktif (Studi Kasus: Balai Diklat Metrologi). STMIK Mardira Indonesia, Bandung: Jurnal Computech \& Bisnis

[12] Yulianto, Erwin., Ilman. Benie. 2018. Simulasi Manajemen Penempatan Barang Pada Gudang
Berbasis 3D Menggunakan Metode Block Stacking. Universitas Langlangbuana, Bandung: Tiarsie

[13] Zhuang, Effendy. 2006. Perangkat Lunak Simulasi Algoritma Banker. Medan: STMIK Mikrosil 